\title{
The Contribution of Learner Self-Assessment for Improvement of Learning and Teaching Process: A Review
}

\author{
Anastasia Papanthymou ${ }^{1} \&$ Maria Darra ${ }^{1}$ \\ ${ }^{1}$ Department of Primary Education, University of the Aegean, Rhodes, Greece \\ Correspondence: Anastasia Papanthymou, Department of Primary Education, University of the Aegean, Rhodes, \\ Dimokratias 1, 85132, Greece. E-mail: premnt15043@rhodes.aegean.gr
}

Received: October 7, 2018

Accepted: November 3, 2018

Online Published: December 30, 2018

doi:10.5539/jel.v8n1p48

URL: https://doi.org/10.5539/jel.v8n1p48

\begin{abstract}
The present study is a literature review of 37 empirical studies from Greece and internationally of the last decade and aims at investigating the contribution of learner self-assessment to: a. enhancement of learning motivation, $\mathbf{b}$. improvement of academic performance/learning, c. development of self-regulating learning and d. raise of self-esteem. According to the findings, enhancement of learning motivation as an outcome of learner self-assessment process has been identified in Greek Higher education, in Secondary education in Physics and in Primary education in English, whereas internationally has been identified in Secondary education in English and Physical education. In Greece, improvement of academic performance/learning as an outcome of learner self-assessment has been found in Higher education, in Secondary education in Physics and in Primary education in English, whereas internationally at all levels of education, in almost all subjects of Secondary education and in Primary education in Language Arts, English and Mathematics. Development of self-regulating learning has been identified in Higher education in Greece and internationally, whereas in Secondary education in Geography and Geometry only internationally. Furthermore, raise of student's self-esteem as an outcome of self-assessment has been found internationally, in Secondary education in Religious education and in Greek Primary education in English language learning. Moreover, self-assessment process has also been examined internationally in non-formal education where English is taught as a second language with positive outcomes in performance/learning. Finally, self-assessment is implemented through various practices and tools such as rubrics, checklist, scripts, think boards, reflective journals, mind maps and in combination with learning or teaching models.
\end{abstract}

Keywords: improvement of academic performance/learning, learning motivation, self-assessment, self-esteem, self-regulating learning

\section{Introduction}

Assessment is the most important aspect of learners' academic life and should direct their learning. Learners who understand the assessment process acquire the ability to learn better (McKevitt, 2016). Learner assessment requires attention as it always has an impact and effect on learners, and it should also help them achieve their goals (Taratori-Tsalkatidou, 2015). New, alternative ways of assessment have been sought to improve learner assessment as there are many who doubt about traditional ways of assessment (Papageorgiou, 2017), such as written tests. Alternative or authentic assessment methods are based on learner's involvement in the assessment process (Chang, Tseng, \& Lou, 2012). One of these methods is learner self-assessment, which is the subject of this review. Keane and Griffin (2016) emphasize the need to revise the current guidelines and practices of world class policy on self-assessment. Moreover, even though there are impressive benefits of learner self-assessment, there is concern about its implementation (Brooks \& Fancourt, 2012). This study presents specific positive outcomes of learner self-assessment and shows how learner self-assessment has been implemented at all levels of education from Primary to Higher education, including non-formal education in order to provide evidence and guidance to researchers about this type of assessment.

Particularly, the present study is a summary of 37 empirical studies and aims at investigating the impact of self-assessment processes on a. motivation for learning, b. improvement of academic performance/learning, c. development of self-regulating learning and $\mathrm{d}$. raise of learner self-esteem, in Greece and internationally the last decade (2008-2018). Furthermore, this study presents ways of implementing learner self-assessment in different 
academic contexts.

\section{Theoretical Framework}

Self-assessment is the ability of learners to assess their performance by making decisions about themselves and their competencies (Chalkia, 2012). It is a type of assessment that serves summative purposes and acts as process that improves learning (Yan, 2018). During self-assessment process learners express their judgment about the effort they make, which may be either autogenous and comes from their personal interest, or heterogenous and comes from someone else (Bellou, 2017). Self-assessment is a very special and important process of the assessment because gives learners the necessary feedback and make them take the appropriate actions to improve (Zapitis, 2011). Especially, it provides internal feedback and helps learners to monitor the gap that there is between their academic performance and the required quality criteria of a task (Hosein \& Harle, 2018). In addition, it is a procedure where learners judge or otherwise assess their work and, especially the quality of their work, in the light of various factors related to their psychology, such as motivation, self-esteem, self-regulation, etc. (Yan \& Brown, 2017). There are different ways that self-assessment can be implemented such as rubrics, learning logs, portfolio, self-assessment tests, which may be also electronic, and forms in which learners can write their judgment about the effort they make, the obstacles they encounter, how they overcome these obstacles, etc. (Petropoulou, Kasimati, \& Retalis, 2015). In order to apply learner self-assessment there are specific stages, which are described in figure 1.

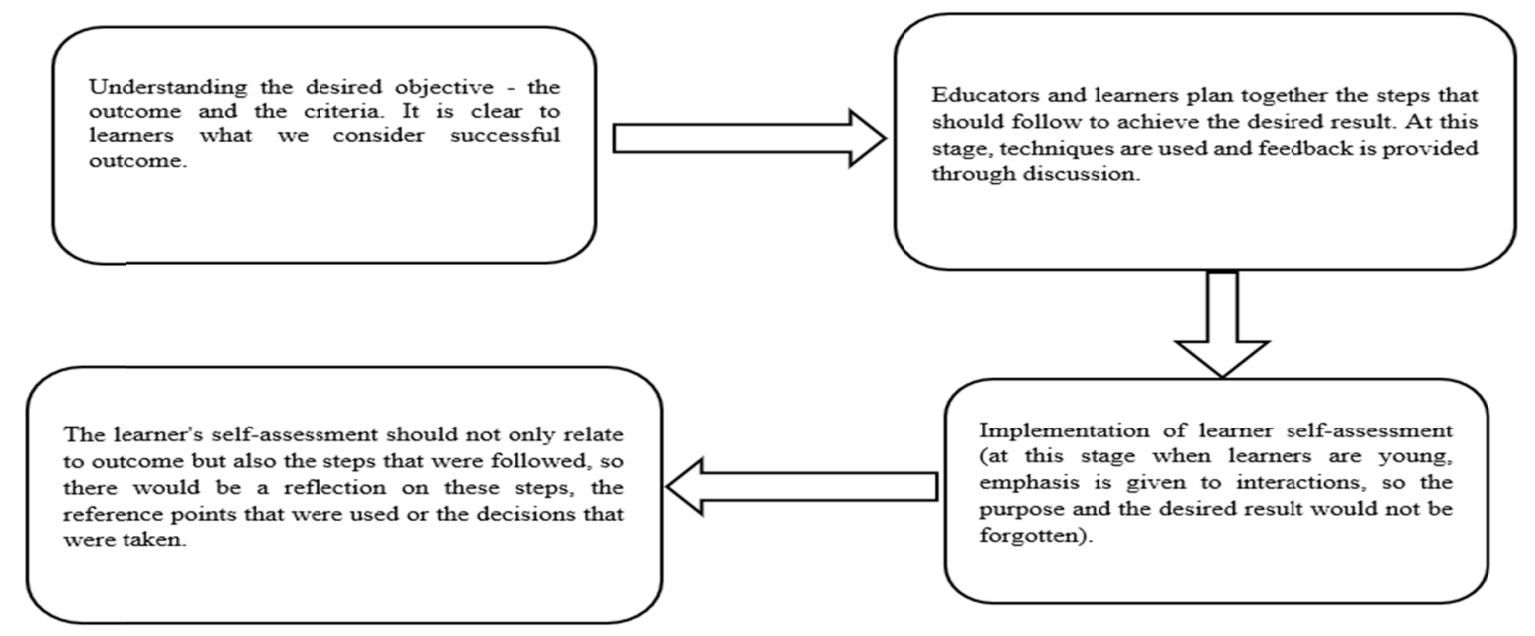

Figure 1. Stages of learner self-assessment

Source: Adjusted from Rekalidou (2011)

\section{Method}

The search of the studies was based on the following assessment criteria, which are presented in the table 1 .

Table 1. Assessment criteria for studies

\begin{tabular}{ll}
\hline Assessment criteria for studies & \\
\hline Research questions & Does the implementation of learner self-assessment \\
& a) enhance learning motivation? \\
& b) improve academic performance/learning? \\
& c) develop self-regulating learning? \\
\hline Geographical distribution & d) raise self-esteem? \\
Year of publication & Global \\
Language & 2008-2018 \\
Type of studies & Greek, English \\
\hline
\end{tabular}

We used the following search machines: Science Direct, Google Scholar, ERIC, ProQuest, OATD, Taylor \& Francis and key-words such as: student/learner self-assessment/self-evaluation/self-appraisal, self-regulation, academic performance/learning, self-esteem, motivation, rubrics, electronic self-assessment, 
higher/secondary/primary education. Also, we used a combination of these key-words for more results. The searches yield 91 papers. We checked the titles and the abstracts and excluded 13 papers, because they were literature reviews. Then, we checked the papers for being relevant to our research aim and excluded 41 papers. Finally, we concluded 37 papers.

\section{Results}

Table 2 presents the examined empirical studies in the context of formal and non-formal education. Formal education includes Higher, Secondary and Primary education and non-formal education includes mainly educational structures where English is taught as a second language.

Table 2. Examined empirical studies

\begin{tabular}{|c|c|c|c|c|}
\hline \multicolumn{5}{|l|}{ Higher education } \\
\hline Researchers (year) & Country & $\begin{array}{l}\text { Research method } \\
\text { (Sample size) }\end{array}$ & $\begin{array}{l}\text { Implementation of } \\
\text { learner self-assessment }\end{array}$ & Main findings \\
\hline 1. Pournias (2009) & Greece & $\begin{array}{l}\text { Quantitative research } \\
\text { ( } 72 \text { students) }\end{array}$ & $\begin{array}{l}\text { Quiz (Quiz report analysis } \\
\text { for moodle). }\end{array}$ & $\begin{array}{l}\text { Development of self-regulating } \\
\text { learning. } \\
\text { Enhancement of learning } \\
\text { motivation. Improvement of } \\
\text { academic performance/learning. }\end{array}$ \\
\hline 2. Tai (2012) & Scotland & $\begin{array}{l}\text { Mixed methods } \\
\text { research design with } \\
\text { sequential explorative } \\
\text { design ( } 251 \\
\text { questionnaires and } 18 \\
\text { interviews with } \\
\text { students) }\end{array}$ & $\begin{array}{l}\text { Learner self-assessment } \\
\text { and Biggs' 3P learning } \\
\text { model. }\end{array}$ & $\begin{array}{l}\text { Development of self-regulating } \\
\text { learning. }\end{array}$ \\
\hline $\begin{array}{l}\text { 3. Wolffensperger \& } \\
\text { Patkin (2013) }\end{array}$ & Israel & $\begin{array}{l}\text { Qualitative research } \\
\text { (17 students and } 2 \\
\text { lecturers) }\end{array}$ & $\begin{array}{l}\text { Learner self-assessment } \\
\text { and co-teaching. }\end{array}$ & $\begin{array}{l}\text { Improvement of academic } \\
\text { performance/learning. }\end{array}$ \\
\hline $\begin{array}{l}\text { 4. Panadero, } \\
\text { Alonso-Tapia \& } \\
\text { Reche (2013) }\end{array}$ & Spain & $\begin{array}{l}\text { Experimental research } \\
\text { (69) }\end{array}$ & $\begin{array}{l}\text { Rubrics } \\
\text { Self-assessment scripts }\end{array}$ & $\begin{array}{l}\text { Development of self-regulating } \\
\text { learning (especially in the case of } \\
\text { self-assessment scripts). }\end{array}$ \\
\hline $\begin{array}{l}\text { 5. Panadero \& } \\
\text { Romero (2014) }\end{array}$ & Spain & $\begin{array}{l}\text { Experimental research } \\
\text { (Quasi-experimental } \\
\text { research, } 218 \\
\text { students) }\end{array}$ & Rubric & $\begin{array}{l}\text { Improvement of academic } \\
\text { performance/learning. }\end{array}$ \\
\hline 6. McKevitt (2016) & Ireland & $\begin{array}{l}\text { Mixed methods } \\
\text { research design ( } 35 \\
\text { students) }\end{array}$ & Rubric & $\begin{array}{l}\text { Improvement of academic } \\
\text { performance/learning. }\end{array}$ \\
\hline $\begin{array}{l}\text { 7. Ozarslan \& Ozan } \\
(2016)\end{array}$ & Turkey & $\begin{array}{l}\text { Quantitative research } \\
\text { (677 students) }\end{array}$ & $\begin{array}{l}\text { Online self-assessment } \\
\text { quiz taking behaviors }\end{array}$ & $\begin{array}{l}\text { Improvement of academic } \\
\text { performance/learning. }\end{array}$ \\
\hline 8. Li \& Chen (2016) & China & $\begin{array}{l}\text { Quantitative research } \\
\text { (60 students) }\end{array}$ & $\begin{array}{l}\text { Combination of self and } \\
\text { peer-assessment }\end{array}$ & $\begin{array}{l}\text { Improvement of academic } \\
\text { performance/learning. }\end{array}$ \\
\hline $\begin{array}{l}\text { 9. Rivas \& Arrufat } \\
\text { (2016) }\end{array}$ & Spain & $\begin{array}{l}\text { Mixed methods } \\
\text { research design ( } 87 \\
\text { students) }\end{array}$ & $\begin{array}{l}\text { Electronic rubrics for self } \\
\text { and peer assessment }\end{array}$ & $\begin{array}{l}\text { Improvement of academic } \\
\text { performance/learning. }\end{array}$ \\
\hline 10. Elgadal (2017) & Libya & $\begin{array}{l}\text { Experimental research } \\
\text { (100 students) }\end{array}$ & $\begin{array}{l}\text { Self-assessment sheet, a } \\
\text { post- study feedback form }\end{array}$ & $\begin{array}{l}\text { Improvement of academic } \\
\text { performance/learning. }\end{array}$ \\
\hline $\begin{array}{l}\text { 11. Fraile, Panadero, } \\
\& \text { Pardo (2017) }\end{array}$ & Spain & $\begin{array}{l}\text { Experimental research } \\
\text { (65 students) }\end{array}$ & $\begin{array}{l}\text { Co-creating rubrics } \\
\text { (learners take part in the } \\
\text { creation of rubrics) }\end{array}$ & $\begin{array}{l}\text { Development of self-regulating } \\
\text { learning. Improvement of } \\
\text { academic performance/learning. }\end{array}$ \\
\hline $\begin{array}{l}\text { 12. Duque Micán \& } \\
\text { Cuesta Medina } \\
\text { (2017) }\end{array}$ & Colombia & $\begin{array}{l}\text { Mixed methods } \\
\text { research design ( } 24 \\
\text { students) }\end{array}$ & $\begin{array}{l}\text { Implementation of } \\
\text { a systematic cycle where } \\
\text { self-assessment is applied } \\
\text { as a formative assessment } \\
\text { source }\end{array}$ & $\begin{array}{l}\text { Improvement of academic } \\
\text { performance/learning. }\end{array}$ \\
\hline 13. Machera (2017) & Botswana & $\begin{array}{l}\text { Quantitative research } \\
\text { (90 students) }\end{array}$ & $\begin{array}{l}\text { Combination of self and } \\
\text { peer assessment }\end{array}$ & $\begin{array}{l}\text { Improvement of academic } \\
\text { performance/learning. }\end{array}$ \\
\hline 14. Ndoye (2017) & USA & $\begin{array}{l}\text { Qualitative research } \\
\text { (16 students) }\end{array}$ & $\begin{array}{l}\text { Combination of self and } \\
\text { peer assessment }\end{array}$ & $\begin{array}{l}\text { Improvement of academic } \\
\text { performance/learning. }\end{array}$ \\
\hline
\end{tabular}




\begin{tabular}{|c|c|c|c|c|c|}
\hline \multicolumn{6}{|l|}{ Secondary education } \\
\hline Researchers (year) & Country & $\begin{array}{l}\text { Research method } \\
\text { (Sample size) }\end{array}$ & Subject & $\begin{array}{l}\text { Implementation of } \\
\text { learner } \\
\text { self-assessment }\end{array}$ & Main findings \\
\hline 1. DeMent (2008) & USA & $\begin{array}{l}\text { Experimental research } \\
\text { (Quasi-experimental } \\
\text { research, } 70 \text { students) }\end{array}$ & $\begin{array}{l}\text { Language } \\
\text { Arts }\end{array}$ & $\begin{array}{l}\text { Portfolio, } \\
\text { self-goal setting, } \\
\text { self-assessment } \\
\text { rubrics, } \\
\text { student-led } \\
\text { conferences with } \\
\text { teacher and parents, } \\
\text { self-assessment scales, } \\
\text { checklists }\end{array}$ & $\begin{array}{l}\text { Improvement of } \\
\text { academic } \\
\text { performance/learning. }\end{array}$ \\
\hline 2. Fancourt (2008) & England & $\begin{array}{l}\text { Qualitative, } \\
\text { ethnographic research } \\
\text { (30 students) }\end{array}$ & $\begin{array}{l}\text { Religious } \\
\text { education }\end{array}$ & $\begin{array}{l}\text { Several techniques } \\
\text { such as "traffic lights", } \\
\text { "use of assessment } \\
\text { criteria", "discussion". }\end{array}$ & $\begin{array}{l}\text { Improvement of } \\
\text { academic } \\
\text { performance/learning. } \\
\text { Raise of self-esteem. }\end{array}$ \\
\hline 3. McDonald (2009) & $\begin{array}{l}\text { Caribbean } \\
\text { country }\end{array}$ & $\begin{array}{l}\text { Mixed methods } \\
\text { research design ( } 515 \\
\text { students) }\end{array}$ & $\begin{array}{l}\text { All subjects } \\
\text { for regional } \\
\text { examination } \\
\end{array}$ & $\begin{array}{l}\text { Self-assessment } \\
\text { training modules. Real } \\
\text { life examples. }\end{array}$ & $\begin{array}{l}\text { Improvement of } \\
\text { academic } \\
\text { performance/learning. }\end{array}$ \\
\hline $\begin{array}{l}\text { 4. Alonso-Tapia \& } \\
\text { Panadero (2010) }\end{array}$ & Spain & $\begin{array}{l}\text { Experimental research } \\
\text { (80 students) }\end{array}$ & Geography & Self-assessment scripts & $\begin{array}{l}\text { Development of } \\
\text { self-regulating } \\
\text { learning. Improvement } \\
\text { of academic } \\
\text { performance/learning. }\end{array}$ \\
\hline $\begin{array}{l}\text { 5. Andrade, Du, \& } \\
\text { Mycek (2010) }\end{array}$ & USA & $\begin{array}{l}\text { Experimental research } \\
\text { (162 students) }\end{array}$ & $\begin{array}{l}\text { Language } \\
\text { Arts }\end{array}$ & $\begin{array}{l}\text { Use of a model essay } \\
\text { for generating criteria. } \\
\text { Self-assessment } \\
\text { rubrics }\end{array}$ & $\begin{array}{l}\text { Improvement of } \\
\text { academic } \\
\text { performance/learning. }\end{array}$ \\
\hline $\begin{array}{l}\text { 6. Panadero, Tapia, } \\
\text { \& Huertas (2012) }\end{array}$ & Spain & $\begin{array}{l}\text { Experimental research } \\
\text { (120 students) }\end{array}$ & Geography & $\begin{array}{l}\text { Rubrics } \\
\text { Self-assessment scripts }\end{array}$ & $\begin{array}{l}\text { Development of } \\
\text { self-regulating learning } \\
\text { (especially in the case } \\
\text { of self-assessment } \\
\text { scripts). Improvement } \\
\text { of academic } \\
\text { performance/learning. }\end{array}$ \\
\hline 7. Thrasher (2012) & USA & $\begin{array}{l}\text { Action research } \\
\text { (25 students) }\end{array}$ & Physics & $\begin{array}{l}\text { Student Learning } \\
\text { Targets Rubric. } \\
\text { Assignment and Effort } \\
\text { Tracking Log. }\end{array}$ & $\begin{array}{l}\text { Improvement of } \\
\text { academic } \\
\text { performance/learning. }\end{array}$ \\
\hline 8. Feldkamp (2013) & USA & $\begin{array}{l}\text { Action research ( } 52 \\
\text { students) }\end{array}$ & Chemistry & $\begin{array}{l}\text { A list of "I can" } \\
\text { statements }\end{array}$ & $\begin{array}{l}\text { Improvement of } \\
\text { academic } \\
\text { performance/learning. }\end{array}$ \\
\hline 9. Yu (2013) & Hong Kong & $\begin{array}{l}\text { Experimental research } \\
\text { (533 students) }\end{array}$ & $\begin{array}{l}\text { Mathematic } \\
\mathrm{s}\end{array}$ & $\begin{array}{l}\text { Think boards } \\
\text { Reflective journals } \\
\text { Mind maps }\end{array}$ & $\begin{array}{l}\text { Improvement of } \\
\text { academic } \\
\text { performance/learning. }\end{array}$ \\
\hline 10. Dalala (2014) & Libya & $\begin{array}{l}\text { Mixed methods } \\
\text { research design ( } 60 \\
\text { teachers) }\end{array}$ & English & $\begin{array}{l}\text { Establishment of } \\
\text { criteria. } \\
\text { Comparison of work } \\
\text { to the criteria and/or } \\
\text { standards. } \\
\text { Provision of feedback. }\end{array}$ & $\begin{array}{l}\text { Enhancement of } \\
\text { learning motivation. } \\
\text { Improvement of } \\
\text { academic } \\
\text { performance/learning. }\end{array}$ \\
\hline 11. Popelka (2015) & USA & $\begin{array}{l}\text { Experimental research } \\
\text { (80 students) }\end{array}$ & $\begin{array}{l}\text { Mathematic } \\
\mathrm{s}\end{array}$ & Rubric & $\begin{array}{l}\text { Improvement of } \\
\text { academic } \\
\text { performance/learning. }\end{array}$ \\
\hline 12. Hatami (2015) & Iran & $\begin{array}{l}\text { Experimental research } \\
\text { ( } 75 \text { students) }\end{array}$ & Geometry & $\begin{array}{l}\text { Learner } \\
\text { self-assessment and } \\
\text { collaborative learning. }\end{array}$ & $\begin{array}{l}\text { Development of } \\
\text { self-regulating } \\
\text { learning. Improvement } \\
\text { of academic } \\
\text { performance/learning. }\end{array}$ \\
\hline
\end{tabular}




\begin{tabular}{|c|c|c|c|c|c|}
\hline $\begin{array}{l}\text { 13. Nikou \& } \\
\text { Economides (2016) }\end{array}$ & Greece & $\begin{array}{l}\text { Experimental research } \\
\text { (66 students) }\end{array}$ & Physics & $\begin{array}{l}\text { Paper and pencil. } \\
\text { Computer-web and } \\
\text { mobile devices. }\end{array}$ & $\begin{array}{l}\text { Enhancement of } \\
\text { learning motivation. } \\
\text { Improvement of } \\
\text { academic } \\
\text { performance/learning } \\
\text { (especially with } \\
\text { computer-based and } \\
\text { mobile- based } \\
\text { self-assessment). }\end{array}$ \\
\hline 14. Peyton (2017) & USA & $\begin{array}{l}\text { Qualitative research } \\
\text { (34 students) }\end{array}$ & $\begin{array}{l}\text { Physical } \\
\text { education }\end{array}$ & Rubric & $\begin{array}{l}\text { Enhancement of } \\
\text { learning motivation. } \\
\text { Improvement of } \\
\text { academic } \\
\text { performance/learning. }\end{array}$ \\
\hline \multicolumn{6}{|l|}{ Primary education } \\
\hline Researchers (year) & Country & $\begin{array}{l}\text { Research method } \\
\text { (Sample size) }\end{array}$ & Subject & $\begin{array}{l}\text { Implementation of } \\
\text { learner } \\
\text { self-assessment }\end{array}$ & Main findings \\
\hline $\begin{array}{l}\text { 1. Andrade, Du, \& } \\
\text { Wang (2008) }\end{array}$ & USA & $\begin{array}{l}\text { Experimental research } \\
\text { (116 students) }\end{array}$ & $\begin{array}{l}\text { Language } \\
\text { Arts }\end{array}$ & $\begin{array}{l}\text { Model of generating } \\
\text { criteria. } \\
\text { Rubric }\end{array}$ & $\begin{array}{l}\text { Improvement of } \\
\text { academic } \\
\text { performance/learning. }\end{array}$ \\
\hline 2. Stylianou (2008) & Cyprus & $\begin{array}{l}\text { Experimental research } \\
\text { ( } 34 \text { students) }\end{array}$ & $\begin{array}{l}\text { Language } \\
\text { Arts }\end{array}$ & Portfolio & $\begin{array}{l}\text { Improvement of } \\
\text { academic } \\
\text { performance/learning. }\end{array}$ \\
\hline $\begin{array}{l}\text { 3. Goto \& Lee } \\
\text { (2010) }\end{array}$ & South Korea & $\begin{array}{l}\text { Experimental research } \\
\text { (254 students) }\end{array}$ & English & $\begin{array}{l}\text { Quiz, role playing } \\
\text { activities, oral } \\
\text { presentations. }\end{array}$ & $\begin{array}{l}\text { Improvement of } \\
\text { academic } \\
\text { performance/learning. }\end{array}$ \\
\hline 4. Zapitis (2011) & Canada & $\begin{array}{l}\text { Action research (46 } \\
\text { students) }\end{array}$ & English & $\begin{array}{l}\text { Learner } \\
\text { self-assessment } \\
\text { training in four stages } \\
\text { (Learner participation } \\
\text { in defining criteria, } \\
\text { teaching how learners } \\
\text { can apply criteria } \\
\text { using a variety of } \\
\text { samples, provision of } \\
\text { feedback to learners } \\
\text { and development of } \\
\text { action plan). }\end{array}$ & $\begin{array}{l}\text { Improvement of } \\
\text { academic } \\
\text { performance/learning. }\end{array}$ \\
\hline 5. Chalkia (2012) & Greece & $\begin{array}{l}\text { Mixed methods } \\
\text { research design ( } 18 \\
\text { students) }\end{array}$ & English & $\begin{array}{l}\text { Self - assessment } \\
\text { checklist }\end{array}$ & $\begin{array}{l}\text { Enhancement of } \\
\text { learning motivation } \\
\text { Improvement of } \\
\text { academic } \\
\text { performance/learning. } \\
\text { Raise of self-esteem. }\end{array}$ \\
\hline $\begin{array}{l}\text { 6. Anastasiadou } \\
\text { (2013) }\end{array}$ & Greece & $\begin{array}{l}\text { Experimental research } \\
\text { (90 students) }\end{array}$ & English & $\begin{array}{l}\text { Leaner self - } \\
\text { assessment through } \\
\text { reflective practice } \\
\text { report with "emphasis } \\
\text { on writing process" } \\
\text { approach. }\end{array}$ & $\begin{array}{l}\text { Enhancement of } \\
\text { learning motivation. } \\
\text { Improvement of } \\
\text { academic } \\
\text { performance/learning. }\end{array}$ \\
\hline 7. Clift (2015) & USA & $\begin{array}{l}\text { Experimental research } \\
\text { (Quasi-experimental } \\
\text { research, } 130 \\
\text { students) }\end{array}$ & $\begin{array}{l}\text { Mathematic } \\
\mathrm{s}\end{array}$ & $\begin{array}{l}\text { Self-assessment with } \\
\text { goal setting. }\end{array}$ & $\begin{array}{l}\text { Enhancement of } \\
\text { learning motivation. } \\
\text { Improvement of } \\
\text { academic } \\
\text { performance/learning. }\end{array}$ \\
\hline \multicolumn{6}{|c|}{ Educational structures where English is taught as a second language } \\
\hline $\begin{array}{l}\text { 1.Birjandi \& Tamjid } \\
\text { (2012) }\end{array}$ & Iran & $\begin{array}{l}\text { Experimental research } \\
\text { (Quasi experiment, } \\
157 \text { students) }\end{array}$ & $\begin{array}{l}\text { English as a } \\
\text { second } \\
\text { language }\end{array}$ & $\begin{array}{l}\text { Journal writing as } \\
\text { self-assessment } \\
\text { technique. } \\
\text { Self-assessment. } \\
\text { Peer assessment. } \\
\text { Both self- and peer } \\
\text { assessment. }\end{array}$ & $\begin{array}{l}\text { Improvement of } \\
\text { academic } \\
\text { performance/learning } \\
\text { (especially in the case of } \\
\text { implementing both self } \\
\text { and peer assessment) }\end{array}$ \\
\hline
\end{tabular}




\begin{tabular}{|c|c|c|c|c|c|}
\hline 2.Heidarian (2016) & Iran & $\begin{array}{l}\text { Experimental research } \\
\text { (48 students) }\end{array}$ & $\begin{array}{l}\text { English as a } \\
\text { second } \\
\text { language }\end{array}$ & $\begin{array}{l}\text { Checklist (Analytic } \\
\text { Scoring Rubric) } \\
\text { Self-Reporting } \\
\text { Questionnaire }\end{array}$ & $\begin{array}{l}\text { Enhancement of learning } \\
\text { motivation. Improvement } \\
\text { of academic } \\
\text { performance/learning. }\end{array}$ \\
\hline
\end{tabular}

Figure 2 presents the number of studies per year.

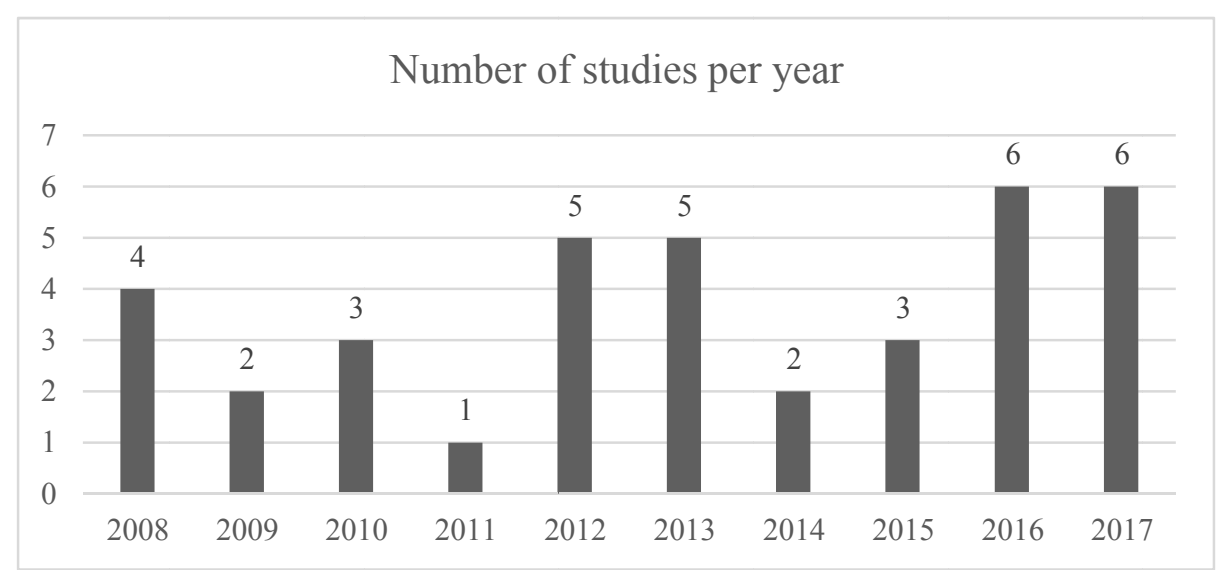

Figure 2. Number of studies per year

Figure 3 presents the number of studies per country.

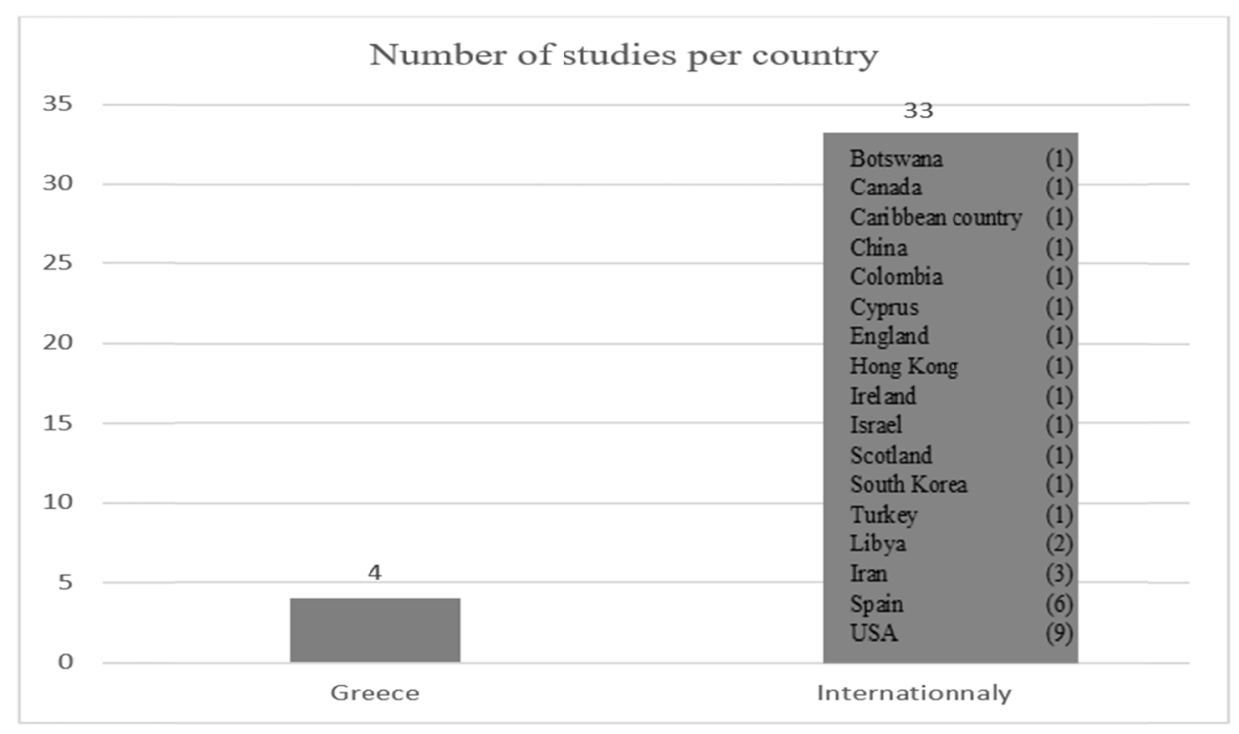

Figure 3. Number of studies per country

Figure 4 presents the research method of studies. 


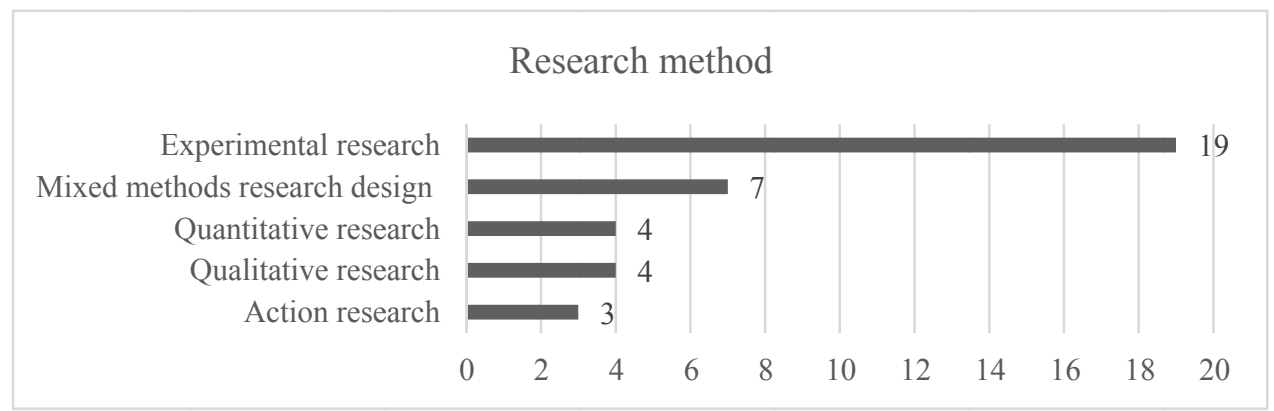

Figure 4. Research method of studies

Figure 5 presents the sample size of experimental studies.

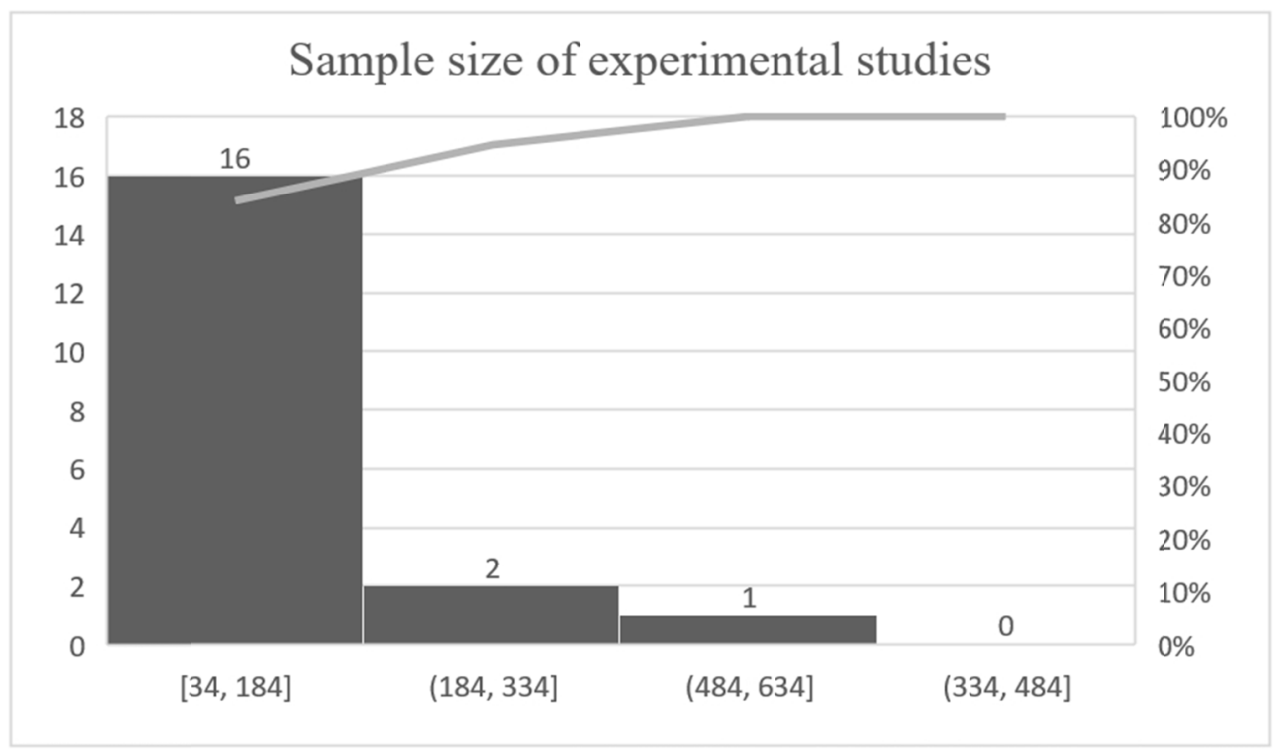

Figure 5. Sample size of experimental studies

Figure 6 presents the sample size of other empirical studies. 


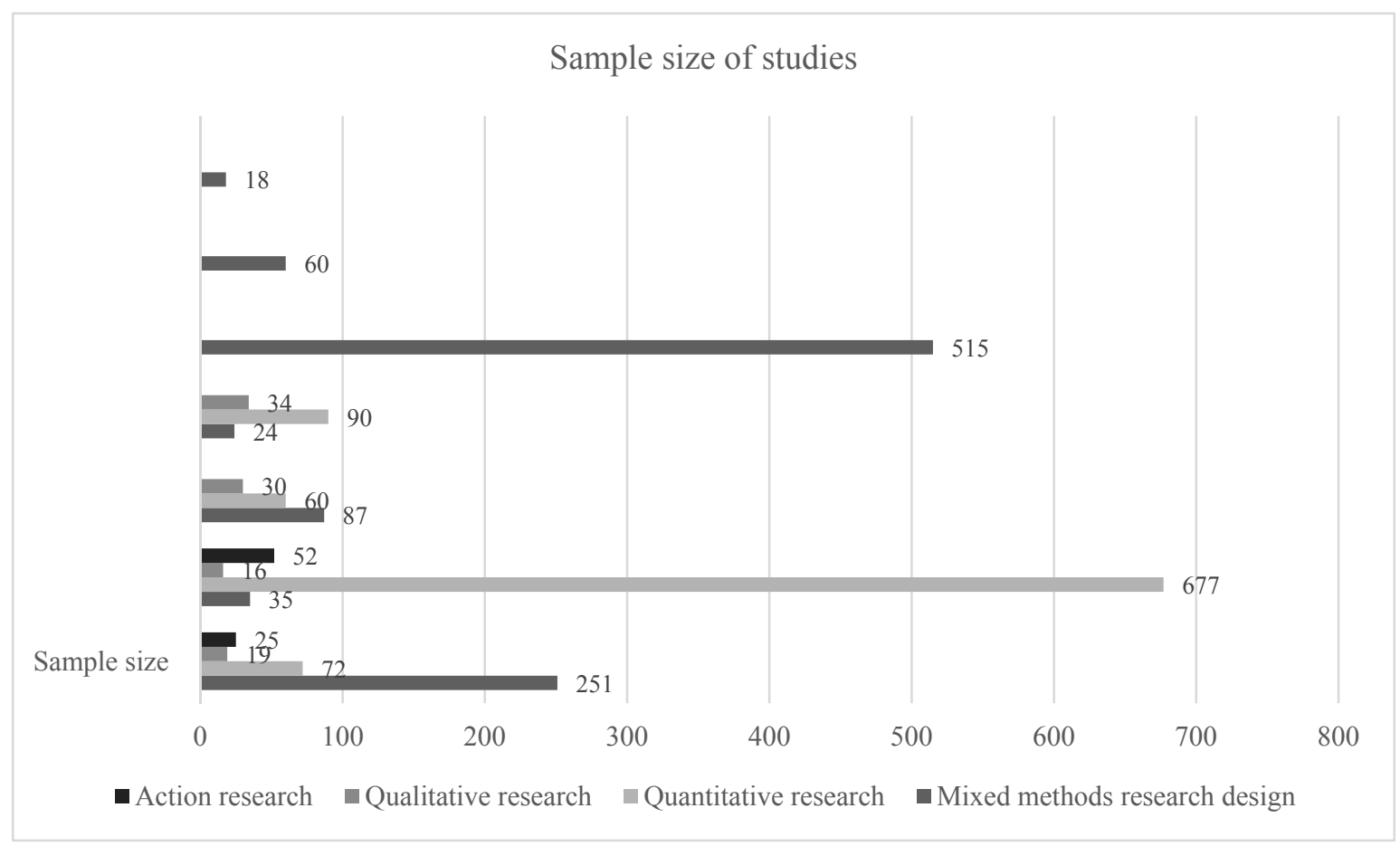

Figure 6. Number of participants of other empirical studies

Figure 7 presents the studies per level of education and the studies which were identified in other educational structures and are relevant to our research aim.

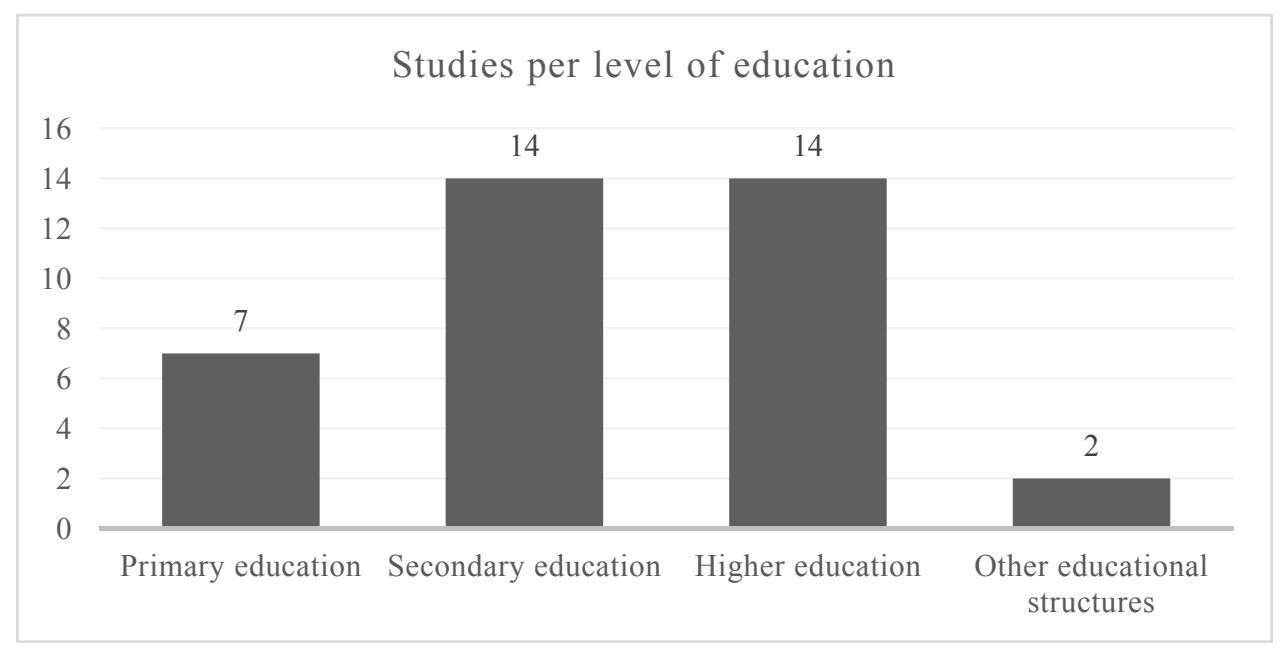

Figure 7. Number of studies per level of education

Figure 8 presents the impact of learner self-assessment in Higher education, especially shows the positive outcomes that self-assessment has on tertiary learners. 


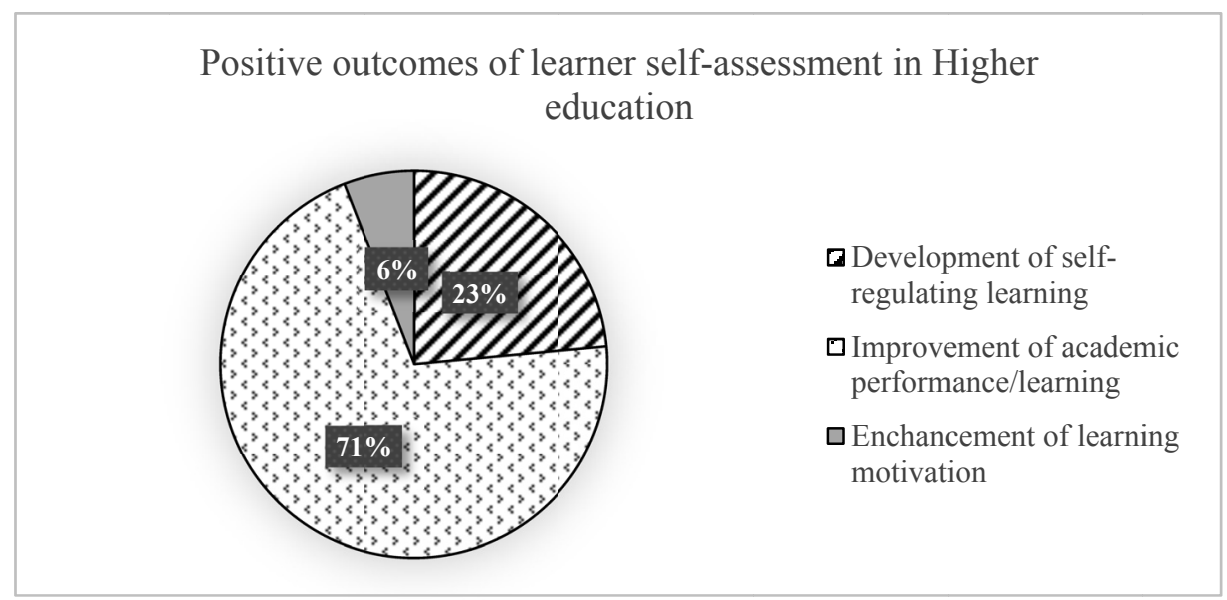

Figure 8. Positive outcomes of learner self-assessment in Higher Education

Figure 9 presents the impact of learner self-assessment in Secondary education per subject, especially shows the positive outcomes that self-assessment has on secondary learners.

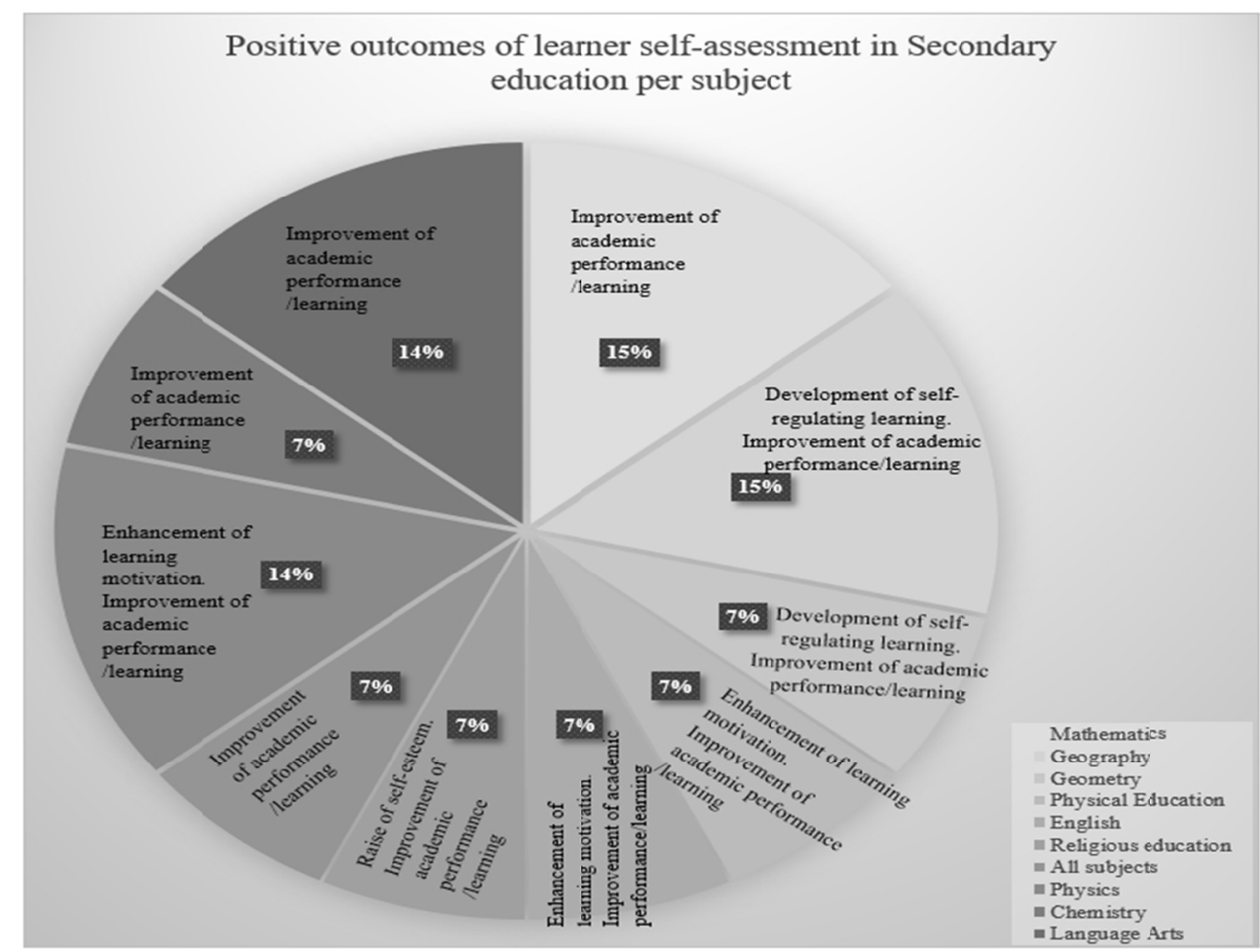

Figure 9. Positive outcomes of learner self-assessment in Secondary education per subject

Figure 10 presents the impact of learner self-assessment in Primary education per subject, especially shows the positive outcomes that self-assessment has on primary learners. 


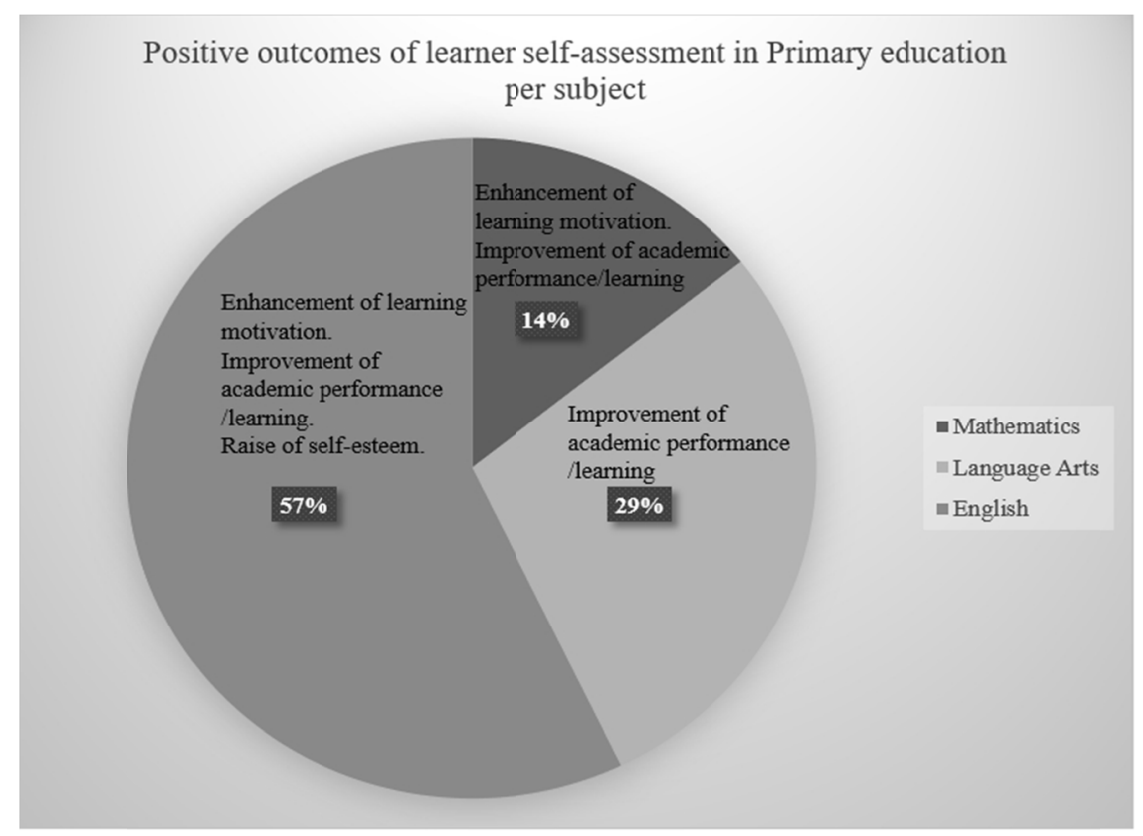

Figure 10. Positive outcomes of learner self-assessment in Primary education per subject

Figure 11 presents the impact of learner self-assessment in other educational structures where English is taught as a second language, especially shows the positive outcomes that self-assessment has on learners.

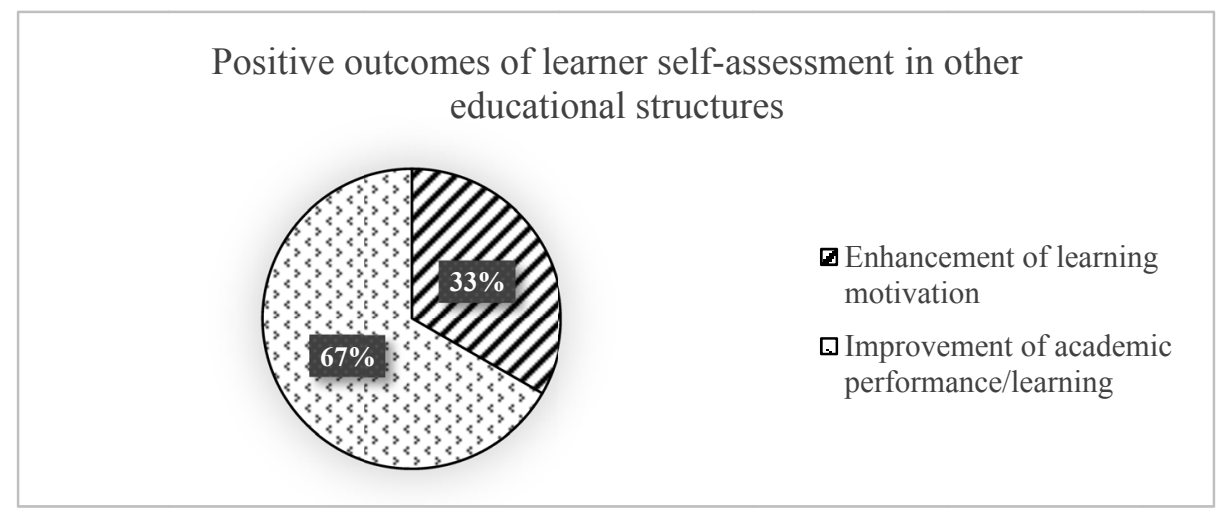

Figure 11. Positive outcomes of learner self-assessment in other educational structures

\section{Discussion}

The average of studies per year that have examined the impact of learner self-assessment on learning, motivation, self-regulating learning, academic performance/learning, or self-esteem is about $(\mathrm{n}=4)$, from 2008 to 2018. In Greece, a minimum number of studies $(n=4)$ has been identified, compared to the international area $(n=33)$.

The most frequent type of research is experimental research $(n=19)$ followed by mixed methods research design $(n=7)$, quantitative research $(n=4)$, qualitative research $(n=4)$ and action research $(n=3)$. Most of experimental studies $(n=16)$ used a sample size with a range of (34-184] participants, only $(n=2)$ studies used a sample size with a range of (184-334] participants and $(n=1)$ study used a sample size with a range of (484-634] participants. For the rest of the empirical studies, quantitative surveys used the largest sample of 677 participants, followed by mixed methods research design with a maximum sample size of 515 participants, action research with 52 participants and qualitative with 34 participants.

According to Panadero, Brown and Strijbos (2016) most research relative to learner self-assessment focuses on 
Higher education. The majority of studies that are relevant to our research aim have been identified in Higher $(n=14)$ and Secondary education $(n=14)$. A small number of studies were found, $(n=7)$ in Primary education and in other educational structures where English is taught as a second language $(\mathrm{n}=2)$.

McMillan and Hearn (2008) in their review underline that learner self-assessment enhances learning motivation. According to the findings of this review, enhancement of learning motivation as an outcome of learner self-assessment has been found in Higher education only in Greece (Pournias, 2009). Internationally, in Secondary education on the subject of Physical education (Peyton, 2017) and English (Dalala, 2014), and in Greek Secondary education on the subject of Physics (Nikou \& Economides, 2016). Internationally, in Primary education, in Mathematics (Clift, 2015), and in Greece in English language learning (Chalkia, 2012; Anastasiadou, 2013). In addition, the positive outcome of self-assessment with regard to learning motivation has been found internationally in other learning structures where English is taught as a second language (Heidarian, 2016).

McMillan and Hearn (2008) and Brown and Harris (2014) support that learner self-assessment contributes to higher achievement. According to the findings of the present study, internationally, improvement of academic performance/learning as a result of learner self-assessment has been found in the context of Higher education (Wolffensperger \& Patkin, 2013; Panadero \& Romero, 2014; McKevitt, 2016; Li \& Chen, 2016; Ozarslan \& Ozan, 2016; Rivas \& Arrufat, 2016; Elgadal, 2017; Fraile et al., 2017; Duque Micán \& Cuesta Medina, 2017; Machera, 2017; Ndoye, 2017) and in Secondary education in Mathematics (Yu, 2013; Popelka, 2015), Language Arts (DeMent, 2008; Andrade et al., 2010), Physics (Thrasher, 2012), Chemistry (Feldkamp, 2013), English (Dalala, 2014), Geometry (Hatami, 2015), Religious education (Fancourt, 2008), Geography (Alonso-Tapia \& Panadero, 2010; Panadero et al., 2012), Physical education (Peyton, 2017) and lastly in all subjects (McDonald, 2009). In Greece, learner self-assessment contributed to the improvement of academic performance/learning in Higher education (Pournias, 2009) and in Secondary education in Physics (Nikou \& Economides, 2016). Moreover, internationally, in Primary education, improvement of academic performance/learning as an outcome of learner self-assessment has been found in Language Arts (Andrade et al., 2008; Stylianou, 2008), English (Goto \& Lee, 2010; Zapitis, 2011) and Mathematics (Clift, 2015), whereas only in English language learning (Chalkia, 2012; Anastasiadou, 2013) in Greece. At this level of education, the contribution of learner self-assessment to improvement of performance/learning has not been examined in other subjects than those mentioned above. As Elder (2010) argues, there is no much research of learner self-assessment in Primary education of academic performance/learning which relates to particular academic tasks. With regard to non-formal learning structures where English is taught as a second language, the positive effect of self-assessment on the performance/learning has been found only internationally (Birjandi \& Tamjid, 2012; Heidarian, 2016).

As highlighted by Brown and Harris (2014), learner self-assessment leads to greater self-regulating learning. Based on research evidence, internationally, development of self-regulation skills as an outcome of learner self-assessment has been found in Higher education (Tai, 2012; Panadero et al., 2013; Fraile et al., 2017) and in Secondary education on the subject of Geography (Alonso-Tapia \& Panadero, 2010; Panadero et al., 2012) and Geometry (Hatami, 2015), whereas only in Higher education (Pournias, 2009) in Greece. In Primary education no research has been identified in international and Greek context.

In addition, raise of learner's self-esteem as an outcome of implementation of self-assessment procedures has been found in Religious Education in Secondary education internationally (Fancourt, 2008), and in Greek Primary education in English language learning (Chalkia, 2012).

For implementing self-assessment process, there are various ways such as tools, practices and/or combination of self-assessment with learning or teaching models. Specifically, in Higher education the use of quizzes such as the quiz report analysis for moodle (Pournias, 2009), the online self-assessment quiz taking behaviors (Ozarslan \& Ozan, 2016), rubrics (Panadero \& Romero, 2014; McKevitt, 2016), electronic rubrics (Rivas \& Arrufat, 2016), self-assessment sheet and post study feedback form (Elgadal, 2017) have a positive effect on academic performance/learning. Moreover, the combination of self and peer assessment (Li \& Chen, 2016; Machera, 2017; Ndoye, 2017), the implementation of a systematic cycle where self-assessment is applied as a formative assessment source (Duque Micán \& Cuesta Medina, 2017), the involvement of learners in creating rubrics (co-creating rubrics) (Fraile et al., 2017) and learner self-assessment within the framework of co-teaching (Wollfensperger \& Patkin, 2013) contribute to the improvement of academic performance/learning. Furthermore, studies have shown that learner self-assessment within the context of the Bigg's 3P learning model (Tai, 2012), the use of scripts (Panadero et al., 2013), the quiz report analysis for moodle (Pournias, 2009) and co-creating rubrics (Fraile et al., 2017) develop self-regulating learning. Lastly, enhancement of learning motivation can be 
achieved using the quiz report analysis for moodle (Pournias, 2009).

In Secondary education, the use of portfolio, self-assessment scales, rubrics, checklist, self-goal setting, student led conferences with teacher and parents (DeMent, 2008), self-assessment training modules and real life examples (McDonald, 2009), self-assessment scripts (Alonso-Tapia \& Panadero, 2010), model essay for generating criteria and rubrics (Andrade et al., 2010), rubrics and scripts (Panadero et al., 2012), student learning targets rubric, assignment and effort tracking log (Thrasher, 2012), list of "I can" statements (Feldkamp, 2013), think boards, reflective journals and mind maps (Yu, 2013), establishment of criteria, comparison of work to the criteria and/or standards and provision of feedback (Dalala, 2014), rubric (Popelka, 2015; Peyton, 2017), learner self-assessment with collaborative learning (Hatami, 2015), computer-based and mobile-based self-assessment (Nikou \& Economides, 2016) contribute to the improvement of academic performance/learning. Several techniques such as "traffic lights", "discussion" and use of assessment criteria (Fancourt, 2008) have a positive effect not only on academic performance/learning but also on self-esteem. Furthermore, from the above, scripts (Alonso-Tapia \& Panadero, 2010; Panadero et al., 2012) and implementation of learner self-assessment with collaborative learning (Hatami, 2015) can develop self-regulating learning. Also, the use of computer-based and mobile-based self-assessment (Nikou \& Economides, 2016), rubric (Peyton, 2017), and the self-assessment procedure that includes establishment of criteria, comparison of a task to criteria and feedback provided to learners can enhance learner's motivation (Dalala, 2014).

In Primary education, the use of portfolio (Stylianou, 2008), rubric and model of generating criteria (Andrade et al., 2008), learner self-assessment training in stages (Zapitis, 2011), quiz, role playing activities and oral presentations (Goto \& Lee, 2010) contribute to the improvement of performance/learning, whereas self-assessment with goal setting (Clift, 2015) and implementation of learner self-assessment through reflective practice report with "emphasis" on writing process approach not only improve performance/learning but also enhance learning motivation (Anastasiadou, 2013). Besides, self-assessment checklist can affect positively learning motivation, self-esteem and performance/learning (Chalkia, 2012).

Self-assessment has been implemented in other educational structures where English is taught as a second language. Especially, the implementation both of self and peer assessment have positive outcome on performance/learning (Birjandi \& Tamjid, 2012), whereas checklist (analytic scoring rubric) and self-reporting questionnaire also influence positively learning motivation (Heidarian, 2016).

\section{Conclusions}

Last decade (2008-2018) most research that examined the contribution of learner self-assessment to motivation for learning, improvement of academic performance/learning, development of self-regulating learning and raise of learner self-esteem has been identified in Higher and Secondary education in contrast to Primary education where it was found only a small number of studies. Therefore, there is need for more research in Primary education. Besides, there is much more research internationally than in Greece and this leads to focus on investigating learner self-assessment in Greek educational reality in the future. Furthermore, it is noticeable that teaching English as a second language in other educational structures such as non-formal education is equally an interesting field of research for examining the outcomes of learner self-assessment process.

Experimental research is the most commonly used method of investigating the effects of self-assessment on learners compared to other types of empirical research. The range of the sample size in most of experimental research is (34-184) of participants.

Internationally, most of the studies that come to the conclusion that learner self-assessment enhances learning motivation have been identified in Secondary education on the subjects of Physical education and English and in Primary education in Mathematics, whereas in Higher education there is no research. In Greece, it was found research in Higher Education, in Secondary education on the subject of Physics and in Primary education in English language learning. Therefore, internationally there is need for examining enhancement of learning motivation as a result of the implementation of self-assessment processes mainly in Higher education, and in Secondary and Primary education in more subjects. In Greek Secondary education research in other subjects such as Geography, Religious education, Mathematics, Chemistry, Language Arts is necessary and in Primary education in other subjects rather than English. Additionally, in international area, learning structures where English is taught as a second language is a field in which the relationship of self-assessment with learning motivation has been explored.

Internationally, the relationship between learner self-assessment and improvement of academic performance/learning has been studied most in Higher Education and in almost all subjects of Secondary education, whereas in Primary education there are less studies and mainly on the subjects of Language Arts, 
Mathematics and English. In Greece, there is a very small number of studies in three levels of education. Especially, it was found one study in Higher education, one study in Secondary education on the subject of Physics and there are two studies in English language learning in Primary education. So, according to what has been examined about the impact of self-assessment on improvement of performance/learning, there is need for more research in Primary education in other subjects such as History, Physical education, Geography, and Religious education in Greece and internationally. Furthermore, the effect of self-assessment on the improvement of learners' performance/learning in other learning structures where English language is taught as a second language has been examined only internationally.

Studies that confirm development of self-regulating learning as an outcome of learner self-assessment have been identified in Higher education internationally and in Greece, whereas in Secondary education on the subjects of Geography and Geometry only in international area. Consequently, internationally in Primary education there is a research gap related to examination of contribution of learner self-assessment to development of self-regulation skills, whereas in Greece there is a gap in Secondary and Primary education.

In addition, raise of learner's self-esteem as an outcome of implementation of self-assessment processes has been identified in Secondary education on the subject of Religious education internationally, and in Greek Primary education in English language learning. Consequently, this leads to the conclusion that there is need for more research in Higher and Primary education internationally, whereas research is required in Greek Higher and Secondary education.

Self-assessment process can be implemented with electronic or non-electronic tools, techniques, practices and/or in combination with various learning or teaching models. Internationally, in Higher education, quizzes such as the quiz report analysis for moodle, the online self-assessment quiz taking behaviors, electronic and non-electronic rubrics, self-assessment sheet and post study feedback form, the combination of self and peer assessment, learner self-assessment within the framework of co-teaching, the implementation of a systematic cycle where self-assessment is applied as a formative assessment source, the involvement of learners in creating rubrics (co-creating rubrics) can improve academic performance/learning. In addition, learner self-assessment within the context of the Bigg's 3P learning model, scripts, the quiz report analysis for moodle and co-creating rubrics develop self-regulating learning. Finally, the use of the quiz report analysis for moodle also contributes to enhancement of learning motivation.

In Secondary education portfolio, rubrics, self-assessment scales, checklists, self-goal setting, student led conferences with teacher and parents, self-assessment training modules, real life examples, self-assessment scripts, model essay for generating criteria, scripts, students learning targets rubric, assignment and effort tracking log, list of "I can statements", think boards, reflective journals, mind maps, establishment of criteria, comparison of work to the criteria and/or standards and provision of feedback, learner self-assessment with collaborative learning, computer-based and mobile-based self-assessment contribute to the improvement of academic performance/learning. Techniques such as "traffic lights", "discussion" and use of assessment criteria not only improve academic performance/learning but also raise self-esteem. Yet, scripts and the combination of learner self-assessment and collaborative learning contribute to development of self-regulating learning. Furthermore, computer-based and mobile-based self-assessment, rubric and the procedure that include establishment of criteria, comparison of work to these criteria and feedback provided to learners enhance learning motivation.

In Primary education portfolio, training in self-assessment, rubric and model of generating criteria, quiz, role playing activities and oral presentations can improve performance/learning. Besides, learner self-assessment with goal setting and self-assessment through reflective practice report with "emphasis" on writing process approach can improve performance/learning and enhance learning motivation. Yet, self-assessment checklist can be beneficial to self-esteem, learning motivation and academic performance/learning.

Internationally, in non-formal education and especially in the context of teaching English as a second language, checklist (analytic scoring rubric) and self-reporting questionnaire can enhance learning motivation, whereas the combination of self and peer assessment can affect positively performance/learning.

\section{Limitations and Proposals for Further Research}

The limitations of this review include the focused search on specific search machines, as well as the examination of specific benefits as an outcome learner self-assessment. Proposals for future research could be the following subjects:

- Literature review that examines other positive outcomes of learner self-assessment such as promotion of 
responsibility, raise of self-efficacy, development of learner autonomy in all levels of education and in non-formal education.

- Empirical research for examining the impact of self-assessment process on improvement of performance/learning, enhancement of learning motivation, development of self-regulating learning and raise of self-esteem in subjects such as History, Geography, Religious education, Language Arts and Mathematics in Greek Primary education.

- Comparison of the effectiveness and ease of use of various tools, practices in self-assessment process.

\section{References}

Alonso-Tapia, J., \& Panadero, E. (2010). Effects of self-assessment scripts on self-regulation and learning. Infancia y Aprendizaje, 33(3), 385-397. https://doi.org/10.1174/021037010792215145

Anastasiadou, A. (2013). Self-assessment: its impact on students' ability to monitor their learning process in the English classroom and develop compensatory strategies. Research Papers in Language Teaching and Learning, 4(1). Retrieved from http://rpltl.eap.gr/current-issue/table-of-contents/18-alexandra-anastasiadou

Andrade, H., Du, Y., \& Wang, X. (2008). Putting rubrics to the test: The effect of a model, criteria generation, and rubric-referenced self-assessment on elementary school students' writing. Educational Measurement: Issues and Practice, 27(2), 3-13. https://doi.org/10.1111/j.1745-3992.2008.00118.x

Andrade, H., Du, Y., \& Mycek, K. (2010). Rubric - referenced self - assessment and middle school students' writing. Assessment in Education: Principles, Policy \& Practice, 17(2), 199-214. https://doi.org/10.1080/09695941003696172

Bellou, E. (2017). Assessment of student performance: A factor that shapes the effectiveness of school's educational work (Master's thesis, University of Ioannina, Ioannina, Greece). Retrieved from http://olympias.lib.uoi.gr/jspui/handle/123456789/28907

Birjandi, P., \& Tamjid, H. (2012). The role of self-, peer and teacher assessment in promoting Iranian EFL learners' writing performance. Assessment \& Evaluation in Higher Education, 37(5), 513-533. https://doi.org/10.1080/02602938.2010.549204

Brooks, V., \& Fancourt, N. (2012). Is self-assessment in religious education unique? British Journal of Religious Education, 34(2), 123-137. https://doi.org/10.1080/01416200.2011.614747

Brown, G. T. L., \& Harris, L. R. (2014). The future of self-assessment in classroom practice: Reframing self-assessment as a core competency. Frontline Learning Research, 2(1), 22-30. https://doi.org/10.14786/flr.v2i1.24

Chalkia, E. (2012). Self-assessment as an alternative method of assessing speaking skills in the sixth grade of a Greek state primary school classroom. Research Papers in Language Teaching and Learning, 3(1). Retrieved from http://rplt1.eap.gr/previous-issues/volume-3-issue-1-february-2012/table-of-contents/37-ekaterini-chalkia

Chang, C., Tseng, K., \& Lou, S. (2012). A comparative analysis of the consistency and difference among teacher-assessment, student self-assessment and peer-assessment in a Web-based portfolio assessment environment for high school students. Computers \& Education, 58(1), 303-320. https://doi.org/10.1016/j.compedu.2011.08.005

Clift, L. (2015). The effects of student self-assessment with goal setting on fourth grade mathematics students: Creating self-regulating agents of learning (Doctoral dissertation, Liberty University, Lynchburg, USA). Retrieved from https://digitalcommons.liberty.edu/cgi/viewcontent.cgi?article=2145\&context=doctoral

Dalala, J. (2014). Investigating the use of the self-assessment processes by Libyan EFL secondary school teachers in assessing students' written work (Doctoral dissertation, University of Sunderland, Sunderland, England). Retrieved from https://ethos.bl.uk/OrderDetails.do;jsessionid=2FC383D8B856E974CA64F4A34594A87C?uin=uk.bl.ethos. 657611

DeMent, L. (2008). The relationship of self-evaluation, writing ability, and attitudes toward writing among gifted Grade 7 language arts students (Doctoral dissertation, Walden University, Minnesota, USA). Retrieved from https://pqdtopen.proquest.com/pubnum/3342482.html

Duque Micán, A., \& Cuesta Medina, L. (2017). Boosting vocabulary learning through self-assessment in an English language teaching context. Assessment \& Evaluation in Higher Education, 42(3), 398-414. 
https://doi.org/10.1080/02602938.2015.1118433

Elder, A. D. (2010) Children's self-assessment of their school work in elementary school. Education 3-13, 38(1), 5-11. https://doi.org/10.1080/03004270802602044

Elgadal, H. (2017). The effect of self-assessment on inexperienced EFL students' writing during revision (Doctoral dissertation, University of Birmingham, Birmingham, England). Retrieved from http://etheses.bham.ac.uk/7558/

Fancourt, N. (2008). Self-assessment in religious education (Doctoral dissertation, University of Warwick, London, England). Retrieved from http://webcat.warwick.ac.uk/record=b2248411 S15

Feldkamp, L. (2013). Effects of self-assessment on student learning in high school chemistry (Master's thesis, Montana State University, Montana, USA). Retrieved from https://scholarworks.montana.edu/xmlui/handle/1/2781

Fraile, J., Panadero, E., \& Pardo, R. (2017). Co-creating rubrics: The effects on self-regulated learning, self-efficacy and performance of establishing assessment criteria with students. Studies in Educational Evaluation, 53(2017), 69-76. https://doi.org/10.1016/j.stueduc.2017.03.003

Goto, B., \& Lee, J. (2010). The effects of self-assessment among young learners of English. Language Testing, 27(1), 5-31. https://doi.org/10.1177\%2F0265532209346370

Hatami, A. (2015). The effect of collaborative learning and self-assessment on self-regulation. Educational Research and Reviews, 10(15), 2164-2167. https://doi.org/10.5897/ERR2015.2349

Heidarian, N. (2016). Investigating the Effect of Using Self-Assessment on Iranian EFL Learners' Writing. Journal of Education and Practice, 7(28). Retrieved from https://files.eric.ed.gov/fulltext/EJ1118573.pdf

Hosein, A., \& Harle, J. (2018). The relationship between students' prior mathematical attainment, knowledge and confidence on their self-assessment accuracy. Studies in Educational Evaluation, 56(2018), 32-41. https://doi.org/10.1016/j.stueduc.2017.10.008

Keane, L., \& Griffin, C. P. (2016). Testing the limits of self-assessment: A critical examination of the developmental trajectories of self-assessment processes. Irish Teachers' Journal, 3(2). Retrieved from https://www.into.ie/ROI/Publications/IrishTeachersJournal2015.pdf\#page=39

Li, Y., \& Chen, L. (2016). Peer-and self-assessment: A Case Study to Improve the Students' Learning Ability. Journal of Language Teaching and Research, 7(4), 780-787. https://doi.org/10.17507/jltr.0704.20

Machera, R. P. (2017). Teaching Intervention Strategies that Enhance Learning in Higher Education. Universal Journal of Educational Research, 5(5), 733-743. https://doi.org/10.13189/ujer.2017.050505

McDonald, B. (2009). Exploring academic achievement in males trained in self-assessment skills. Education 313, 37(2), 145-157. https://doi.org/10.1080/03004270802069244

McKevitt, C. (2016). Engaging Students with Self-Assessment and Tutor Feedback to Improve Performance and Support Assessment Capacity. Journal of University Teaching and Learning Practice, 13(1). Retrieved from https://ro.uow.edu.au/cgi/viewcontent.cgi?referer=https://www.google.gr/\&httpsredir=1\&article=1561\&con text=jutlp

McMillan, J. H., \& Hearn, J. (2008). Student self-assessment: The key to stronger student motivation and higher achievement. Educational Horizons, 87(1). Retrieved from https://eric.ed.gov/?id=EJ815370

Ndoye, A. (2017). Peer/Self-Assessment and Student Learning. International Journal of Teaching \& Learning in Higher Education, 29(2). Retrieved from https://files.eric.ed.gov/fulltext/EJ1146193.pdf

Nikou, S. A., \& Economides, A. A. (2016). The impact of paper-based, computer-based and mobile-based self-assessment on students' science motivation and achievement. Computers in Human Behavior, 55, 1241-1248. https://doi.org/10.1016/j.chb.2015.09.025

Ozarslan, Y., \& Ozan, O. (2016). Self - Assessment Quiz Taking Behaviour Analysis in an Online Course. European Journal of Open, Distance and E-learning, 19(2), 15-31. https://doi.org/10.1515/eurodl-2016-0005

Panadero, E., Tapia, J., \& Huertas, J. (2012). Rubrics and self-assessment scripts effects on self-regulation, learning and self-efficacy in secondary education. Learning and individual differences, 22(6), 806-813. https://doi.org/10.1016/j.lindif.2012.04.007

Panadero, E., Alonso-Tapia, J., \& Reche, E. (2013). Rubrics vs. self-assessment scripts effect on self-regulation, 
performance and self-efficacy in pre-service teachers. Studies in Educational Evaluation, 39(3), 125-132. http://dx.doi.org/10.1016/j.stueduc.2013.04.001

Panadero, E., \& Romero, M. (2014). To rubric or not to rubric? The effects of self-assessment on self-regulation, performance and self-efficacy. Assessment in Education: Principles, Policy \& Practice, 21(2), 133-148. https://doi.org/10.1080/0969594X.2013.877872

Panadero, E., Brown, G. T., \& Strijbos, J. W. (2016). The future of student self-assessment: a review of known unknowns and potential directions. Educational Psychology Review, 28(4), 803-830. https://doi.org/10.1007/s10648-015-9350-2

Papageorgiou, K. A. (2017). Alternative assessment proposals for primary education. Proceedings of the 9th International Conference on Open \& Distance Learning, 9, 150-159. http://dx.doi.org/10.12681/icodl.1120

Petropoulou, O., Kasimati, A., \& Retalis, S. (2015). Contemporary educational assessment with the use of educational technologies. Retrieved from http://hdl.handle.net/11419/233

Peyton, C. (2017). Students' Perception of the Self-Assessment Process in High School Physical Education (Master's thesis, Illinois State University, Illinois, USA). Retrieved from https://ir.library.illinoisstate.edu/cgi/viewcontent.cgi?article=1771\&context=etd

Popelka, E. (2015). Improving the accuracy of middle school students' self-assessment, peer assessment, and mathematics achievement (Doctoral dissertation, University of Louisville, Louisville, Kentucky). Retrieved from

https://ir.library.louisville.edu/cgi/viewcontent.cgi?referer=https://www.google.gr/\&httpsredir=1\&article=3 295\&context=etd

Pournias, A. (2009). Expanding the moodle learning management system to present learner self-assessment results (Master's thesis, University of Piraeus, Piraeus, Greece). Retrieved from http://dione.lib.unipi.gr/xmlui/handle/unipi/3080

Rekalidou, G. (2011). Assessment of learning or assessment for learning? Athens: Pedio Publications.

Rivas, M. R., \& Arrufat, M. J. G. (2016). University Students' Perceptions of Electronic Rubric-Based Assessment. Digital Education Review, $30 . \quad$ Retrieved from http://revistes.ub.edu/index.php/der/article/view/15442

Stylianou, M. (2008). Student self-assessment based on Portfolio Assessment as a means of developing communication skills, and especially understanding and producing of writing (Master's thesis, Aristotle University of Thessaloniki, Thessaloniki, Greece). Retrieved from http://amaked-thrak.pde.sch.gr/symdim-kav4/pdf/h_auyoaksiologhsh_me_Portfolio.pdf

Tai, C. (2012). Undergraduate business and management students' experiences of being involved in assessment (Doctoral dissertation, University of Edinburgh, Edinburgh, Scotland). Retrieved from https://www.era.lib.ed.ac.uk/handle/1842/9456

Taratori-Tsalkatidou, E. (2015). School Assessment: Assessment of the school, teacher and student's performance. Thessaloniki: Kiriakidis Bros Publications S.A.

Thrasher, B. (2012). The effects of student self-assessment in science (Master's thesis, Montana State University, Montana, USA). Retrieved from https://scholarworks.montana.edu/xmlui/handle/1/2423

Wolffensperger, Y., \& Patkin, D. (2013). Self-assessment of self-assessment in a process of co-teaching. Assessment \& Evaluation in Higher Education, $38(1), \quad 16-33$. https://doi.org/10.1080/02602938.2011.596925

Yan, Z., \& Brown, G. (2017). A cyclical self-assessment process: towards a model of how students engage in self-assessment. Assessment \& Evaluation in Higher Education, 42(8), 1247-1262. https://doi.org/10.1080/02602938.2016.1260091

Yan, Z. (2018). Student self-assessment practices: the role of gender, school level and goal orientation. Assessment in Education: Principles, Policy \& Practice, 25(2), 183-199. https://doi.org/10.1080/0969594X.2016.1218324

$\mathrm{Yu}, \mathrm{T}$. (2013). The use of self-assessment to facilitate self-directed learning in mathematics by Hong Kong secondary school students (Doctoral dissertation, Durham University, Durham, England). Retrieved from http://etheses.dur.ac.uk/6995/ 
Zapitis, M. (2011). The effects of self-evaluation training on writing of students in grades 5 \& 6 (Master's thesis, University of Toronto, Toronto, Canada). Retrieved from https://tspace.library.utoronto.ca/bitstream/1807/29492/1/Zapitis_Marina_201106_MA_thesis.pdf

\section{Copyrights}

Copyright for this article is retained by the author, with first publication rights granted to the journal.

This is an open-access article distributed under the terms and conditions of the Creative Commons Attribution license (http://creativecommons.org/licenses/by/4.0/). 